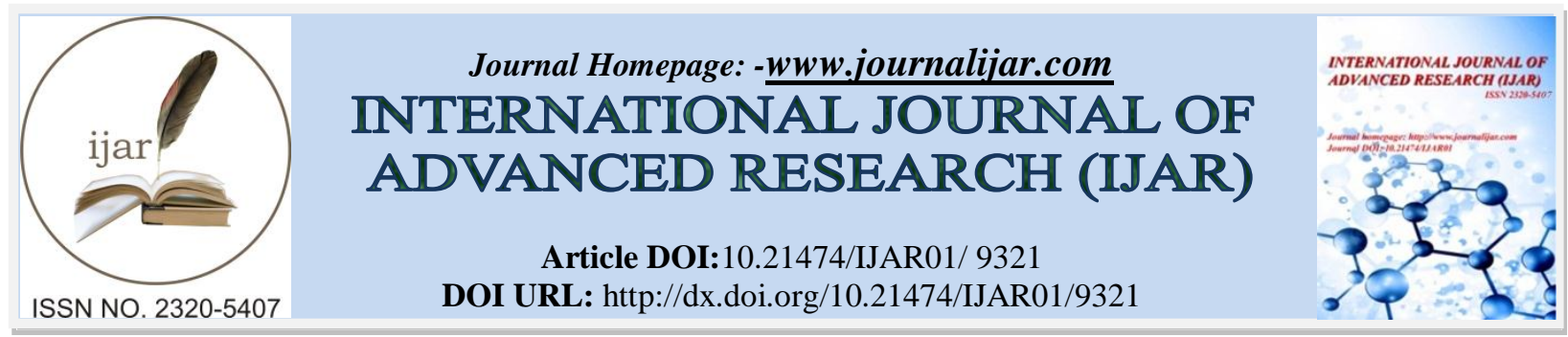

RESEARCH ARTICLE

\title{
RESTORATIVE JUSTICE: THE RESTORABLE LEGAL FACT.
}

Oscar Daniel Franco Conforti.

Department of Criminal Law and Department of Restorative Justice, School of Law, University Center of Baja California, Tijuana, Mexico.

\section{Manuscript Info}

\section{Manuscript History}

Received: 02 May 2019

Final Accepted: 04 June 2019

Published: July 2019

\begin{abstract}
Restorative Justice is one of the methodologies that present itself as a more humanitarian justice closer to the victims of a crime. Firstly, Restorative Justice is a key piece in the relief of Courts and Tribunals for the legislator and some legal operators; secondly, the investment in this practice means a reduction of judicial budget. Crime usually causes material damage as well as psychological damage, which is less visible. The psychological damage may not be quantified, economically as moral damage and it usually does not receive attention within the traditional criminal justice system. On the one hand, the abolitionists consider that Restorative Justice should replace Criminal Law. On the other hand, it constitutes a Third Way that would be halfway between security measures and punishment. Finally, there is a third position that advocates for the achievement of a new way of conceiving the justice concept, which is closer to the philosophical principles of Peace: This is a new conception through social transformation. The aim of this article is to review some concepts that must be clear when we think about ways to help the Civil Law system to introduce the restorative practices at the Criminal Law system successfully.
\end{abstract}

Copy Right, IJAR, 2019,. All rights reserved.

\section{Introduction:-}

Under the greater premise of the decriminalization or loss of the central role of the law in favor of a dispositive principle (that is, for certain cases in which some available nature subjective rights become affected) some new modernization of justice policies are currently undergoing.

Legal operators should take special care and pay close attention to the message they want to convey otherwise their way of expressing tends to confuse terms and the citizens.

Does the State 'Steal' the crime from the citizens?

To look into this matter one has to go back in history and think about the 'self-protection of rights or Private Justice', that social phenomenon by which the person offended or affected in their rights reacts against the person or property of the offender (de la Oliva Santos et al 2009).

Abolishing the Private Justice has given rise to the jurisdictional function of the State.

Corresponding Author:-Oscar Daniel Franco Conforti.

Address:-Department of Criminal Law and Department of Restorative Justice, School of Law, University Center of Baja California, Tijuana, Mexico. 
It has been us, the individuals considered individually, who form a family, a group, a population, a nation, and have ceded part of our rights in favor of the 'State', which has since then assumed the commitment of the effective judicial protection; otherwise, Social Peace, which is the very foundation of the existence of a nascent 'community', would be unfeasible.

This thesis has been argued at the First World Congress of Alternative Justice held in the City of Tijuana, Mexico from August 22nd to 23rd, 2017 and it is based on the positions of very important jurists of the Civil Law System like Cesare Bonesana (known to may as Marquis of Beccaria) and Francesco Carnelutti (Conforti 2017a).

From this legal approach the conclusion is:

1. The State has not appropriated more than what the citizens have given to it.

2. It is clear that the 'Right to Effective Judicial Protection' (citizens level) should not be confused with the 'Exercise of Effective Judicial Protection' (Judges and Courts levels) (Conforti 2017b).

\section{New approach in criminal Law}

Under the premise that the 'Restorative Justice' has come to cover a need within the scope of Criminal Law, in the justice system of Civil Law some pilot programs of Restorative Practices have been developed.

In many cases, restorative practices have been fit into the procedural framework 'in the best possible way', and one of the reasons why this is so is that Restorative Practices have not found an 'easy' justification to insert into the criminal sphere. Criminal norms and criminal procedures do not foresee their practical application, due to this fact, many magistrates, persuaded and convinced of their practical use, did not know how to react before such situation because they could not find criminal legal arguments to apply the practice of Criminal Law.

It is imperative thus to study the Restorative Practice from the legal concept of criminal offense, which will involve the review of an important number of concepts already known, (fact, act, event, action, offense, damage, tangible, intangible, etc.) and confirm, marking another important difference, that the recipient of the Restorative Practice is none other than the Community or Society, although the protagonism may fall on the person (physical or legal) who has been the material victim of the crime.

\section{Extensions of the Justice conceptions}

Justice Conceptions are multiple, starting with Aristotle, it is possible to find two theories about the concept of Justice which have been developed by Thomas Aquinas, Bentham, Mill, Nozick, Friedman, Locke, Kant, and Ralws among others. It is easy to conclude that Justice depends on the individual beliefs of each person and the values of a society, however, there are different theories (Conforti 2017c).

The first theory is about giving each person what corresponds to them on the basis of material truth. It would be within the retributive approach, where the idea of Justice corresponds with the determination of the real facts, that is, with the material truth.

The second theory deals with the freedom of choice to decide what to do according to the moral self-imposed principles. We would be within the restorative approach, where the idea of Justice consists of doing what is right, that is, what should be done at a particular situation (Conforti 2017d).

\section{Two types of notions of crime}

We need to pay special attention, since, in the Civil Law, not every 'illicit act' is constitutive of 'crime.' To differentiate the 'unlawful civil act' from the 'criminal act', the simplest method is to pay attention to the type of sanction or punishment that they receive, that is, 'there is an unlawful civil act when the act is punished with various penalties' and 'there is a criminal offence when the penalty is applied against it'.

Even today criminal law struggles against certain doctrinal currents that are usually inspired by other sciences that, of course, consider and define crime under other aspects that have nothing in common with the legal one.

To cite the most common case: 'from the sociological point of view a fact is a crime because it is contrary to the common good, or, in other words, harmful to society.' (Carnelutti 1952, 16). 


\section{Three conceptions of the legal fact}

Carnelutti led us to distinguish between the 'fact' and the 'legal act', followed by the 'action crimes' and 'event crimes'. He proceeds with the categories (a) 'legal fact repairable' and the (b) 'legal fact punishable'; all this development inspired me to create a new category of legal fact, I am referring to the (c) 'restorable legal fact'.

The studies and approach start at the legal fact and if someone should ask why 'legal fact' instead of 'legal act'?, the answer would be simple: because it is precisely there, in the 'process' of compression or conversion of legal facts to legal acts where criminal science loses sight of 'restorable juridical facts'.

To facilitate the understanding of the subtle differentiation and classification operated; it will be necessary to keep in mind the difference between 'action and event', that is, the 'dynamic and static' moments of crime, respectively.

It is also very important to be clear about some key concepts such as 'offense' and 'harm', and at the same time the relationship between both of them.

From the dynamic approach of the crime, the offense corresponds to the author, who injures, while from the static approach, the damage corresponds to the injury of a legally protected interest.

We have already seen that the focus of this article falls on a new category of 'legal fact':

1. The 'punishable legal fact', for example: crime and offenses.

2. The 'legal fact reparable' (compensable), for example: the damage is in default, material damage and any type of damage or quantifiable injury, that is, the tangible.

3. The 'restorable legal fact', for example: the trauma that remains in the material victim of a crime of rape due to injury to the woman's interest in arriving as a virgin at marriage or of dying a virgin according to her religious faith, that is, the intangible aspects.

According to the legal bases developed in this article, within the general theory of crime, the restorable legal fact is perfectly distinguished from the repairable legal fact as follows:

Table 1:- Comparative Legal Fact Repairable vs. Legal Fact Restorable.

\begin{tabular}{|l|l|}
\hline \multicolumn{1}{|c|}{ Repairable Legal Fact } & \multicolumn{1}{|c|}{ Restorable Legal Fact } \\
\hline $\begin{array}{l}\text { It arises from the compression of the 'facts' to 'legal } \\
\text { acts' }\end{array}$ & $\begin{array}{l}\text { It remains at the varie figurae zone in the operation of } \\
\text { compression of the 'facts' to the 'legal acts' }\end{array}$ \\
\hline $\begin{array}{l}\text { It is represented with a 'static moment' (a picture of the } \\
\text { crime) }\end{array}$ & It is represented as a 'dynamic moment' (a movie) \\
\hline It fits into the 'crimes of event' & It falls within the 'crimes of action' \\
\hline The mandad of repairation arises from 'the Law' & The mandad of restoration arises from 'moral duty' \\
\hline $\begin{array}{l}\text { Within the criminal science it responds to the idea of } \\
\text { 'Harm' }\end{array}$ & $\begin{array}{l}\text { Within the criminal science it responds to the idea of } \\
\text { 'Offense' }\end{array}$ \\
\hline $\begin{array}{l}\text { Its constituent elements are 'Injury and Disobedience' } \\
\text { It is composed of 'the evil of human action and injury to } \\
\text { an alien interest' }\end{array}$ \\
\hline $\begin{array}{l}\text { Address the 'damaged object and the injury of a foreign } \\
\text { interest' }\end{array}$ & $\begin{array}{l}\text { Serves the 'offender-offended binomial and the } \\
\text { instrument of offense' }\end{array}$ \\
\hline It is susceptible of economic valuation & It is not susceptible of economic valuation \\
\hline It is compensable & It does not admit compensation \\
\hline Responds to the concept of Tangibility & Responds to the concept of Intangibility \\
\hline
\end{tabular}

\section{Own elaboration}

What we must ask ourselves is: 'What aspect of the legal fact called crime are we talking about?', Its aspect (a) punishable, (b) repairable/tangible, or (c) restorable/intangible.

It is important to have these criminal legal concepts very clear because this will help to understand that because the forced conversion of the 'Intangible' into 'Tangible' does not mean that some 'intangible' aspects that have evidently not been overcome with economic compensation and that often require receiving a genuine and authentic 
apology and at the same time having the capacity to grant forgiveness, have not fallen out of said conversion operation.

Creating the category 'Restorable Legal Fact' from the criminal science allows to build a new institute, that is, the 'Restoration Institute'. And this is not minor because it comes to correct all the drawbacks of the alleged insertion of the erroneously named 'Restorative Justice' allowing criminal legal science to accept the 'restorative principles'.

\section{The restorative legal fact}

Conceived the idea of the Institute of the Restoration within the Criminal Law, assuming that it is impossible to talk about crime without 'event' (harm) and without 'action' (offense), and taking as a starting point the distinction between the categories of crimes: a) 'crimes of action' and b) 'crimes of event', the proposal is that when considering the change from the point of view of the offense, that is, the way in which it has taken place, such consideration is done in such a way as to carry forward the effective incorporation of the legal facts that fall into oblivion when the conversion of 'material facts' into 'legal acts' is carried out.

This 'legal fact' has been called 'restorable legal fact'.

The explanation of why Criminal Law cannot contemplate all the injuries of interests other than the factual fact or the objective material fact is that in order to fulfill its purpose, the Law must compress the 'fact' into a 'species', that is, to turn the material fact into a 'fact in question' (Carnelutti 2006).

There seems to be a consensus to admit that by compressing the 'facts' into 'acts', in order to be present and subject to the legal process, something is lost along the way.

Between the compression of the material facts and the legal acts there is a zone of variae figurae where a good part of the material facts have fallen into oblivion (probably due to the degree of difficulty to warn them and the even heavier burden of explaining them), remaining until now unexplored from the legal.

\section{Conclusion:-}

It is indispensable to not neglect the crimal dogmatic in the design of restorative practices and therefore it is advisable to keep in mind the following clarifications:

1. It is imperative to do the distinctions between the concepts from the different disciplines and Law Science.

2. Crime and 'consequences of the crime' coexist and they are not incompatible with each other.

3. Retributive and restorative approaches can be integrated into the same and only process within the Civil Law System because they are complementary.

4. The 'restorable legal fact' is the fact that 'is not economically valued or compensable in economics terms'; it is the intangible component of the crime.

5. The 'restorable legal fact' is directly related to the offense and could assimilate, by analogy, to the criminal conflict.

6. In such a way, the legal litigation or crime, and at the same time the intangible component of the crime, which is to say, the 'restorable legal fact', can be sorted out in the same process.

7. The emphasis placed on the restorative principles and values and their differences between the diverse disciplines, such as, for example, sociology, criminology and legal science, only seek to serve as the bases of the newly developed theory on the 'restorable legal fact', which is a new category of legal fact which refers to the 'intangible component of the crime' described above (Conforti 2019). 


\section{Bibliography:-}

1. Carnelutti, F. (1952). General Theory of Crime. Trans. V. Conde Madrid: Private Law Magazine.

2. Carnelutti, F. (2006). Art of Law. Methodology of Law. Buenos Aires: Library The Forum.

3. Conforti O.D.F. (2017a). How to improve the Criminal Law. First World Congress of Alternative Justice. Conference Paper at CUBC University, Tijuana, Mexico. August 22nd-23rd, 2017.

4. Conforti O.D.F.(2017b). From e-Mediation to On-line Restorative Justice in Criminal Law. American Journal of Engineering and Technology Management. Vol. 2, No. 5, 2017, pp. 56-63. doi: 10.11648/j.ajetm.20170205.11

5. Conforti O.D.F. (2017c). Effective Judicial Protection and Conflict Mediation in Spain. Tecnos. Spain.

6. Conforti O.D.F. (2017d). From e-Mediation to On-line Restorative Justice in Criminal Law. American Journal of Engineering and Technology Management. Vol. 2, No. 5, 2017, pp. 56-63. doi: 10.11648/j.ajetm.20170205.11.

7. Conforti O.D.F. (2018). ODR and Restorative Justice Online: clrarifying concepts due to its legal implications. International Journal of Advanced Research (IJAR). Article DOI: 10.21474/IJAR01/6293. DOI URL: http://dx.doi.org/10.21474/IJAR01/6293

8. Conforti O.D.F. (2019). The Restorative Legal Fact, Ways to Help the Civil Law System to Introduce the Restorative Practices at the Criminal Law System in L. Cavalcanti Castro editor. Criminal Law: Past, Present and Future Perspectives. Nova Science Publishers, Inc., New York.

9. de la Oliva Santos, A., and Peitado Mariscal, P. (2009). Effective Judicial Protection System. Madrid: Financial Studies Center. 